\title{
Criminal Acts Performed by Children in the Perspective of Criminology (Case Study in Gorontalo City on 2008-2012)
}

\section{Mohamad Taufiq Zulfikar Sarson ${ }^{1^{*}}$}

1 Faculty of Law, Universitas Negeri Gorontalo, Indonesia

*Corresponding Author: M. T. Zulfikar Sarson, email: mtaufiqzulfikars@gmail.com

\begin{abstract}
This study aims to determine the factors that lead to criminal offenses committed by children in the city of Gorontalo and how the response to the occurrence of criminal offenses committed by children in the city of Gorontalo. Data were collected through interviews, questionnaires. Analysis of the data used is data analysis that seeks to provide a clear and concrete description of the object that are discussed qualitatively and then the data is presented in descriptive technique that uses a frequency distribution test with the formula $\mathrm{P}=\mathrm{F} / \mathrm{N} \mathrm{x}$ $100 \%$. The results showed that the root causes of criminal offenses committed by children in the city of Gorontalo is the environmental factor family and social environment, socio-economic condition factor, factor the low level of education, liquor as psychological factors, and factors that are less religious knowledge. Efforts to control criminal offenses committed by children in the city of Gorontalo there are three forms: preventive countermeasures (prevention), attempts repressive and rehabilitation efforts
\end{abstract}

Keywords: Juvenile Crime, Criminology, Children, Crime Prevention

\section{How to cite:}

Sarson, M.T.Z. (2020). Criminal Acts Performed by Children in the Perspective of Criminology (Case Study in Gorontalo City on 2008-2012). Indonesian Journal of Advocacy and Legal Services, 1(2), 205-222. DOI: 10.15294/ijals.v1i2.36094

\section{A. Introduction}

Crime is an act that has been perpetually carried out by humans from the past until today. Humans do bad deeds both to themselves and to others. 
Evil behavior is carried out by anyone, both women and men, can take place in children and adults. Evil is a name or stamp given by people to judge certain actions, as evil deeds. Thus the offender is called a criminal. This understanding comes from the realm of values, so it has a very relative understanding, that is, it depends on the human being who gives that judgment. So what is called a crime by someone is not necessarily recognized by other parties as a crime anyway. Even if for example all groups can accept something that is a crime but the severity of the act still causes differences of opinion. ${ }^{1}$

Children are an inseparable part of human survival and the survival of a nation and state, in the Indonesian constitution, children have a strategic role, this is expressly stated that the State guarantees every child the right to survival, growth, and development as well as the right to protection from violence and discrimination. Children are a mandate from God Almighty which is inherently inherent in their dignity and as a whole human being. Every child has dignity and worth that is upheld and every child born must get his rights without the child asking. This is in accordance with the provisions of the Convention on the Rights of the Child ratified by the Indonesian government through Presidential Decree Number 36 of 1990, then also set forth in Law Number 4 of 1979 concerning Child Welfare and Law Number 23 of 2002 on Child Protection all of which revealed general principles of child protection, namely non-discrimination, the best interests of children, survival and development, and respect for children's participation. $^{2}$

The problem of children today, is still a very actual problem where almost all countries in the world in general and Indonesia in particular, attention to the problem of child delinquency has been widely discussed among the public, seminars that have been conducted by several institutions and women's and children's observer organizations, as well as government

\footnotetext{
Anggie Rizqita Herda Putri \& Ridwan Arifin, Perlindungan Hukum Bagi Korban Tindak Pidana Perdagangan Orang Di Indonesia (Legal Protection for Victims of Human Trafficking Crimes in Indonesia), Res Judicata, Vol. 2 No. 1, 2019, pp. 170-185. DOI: http://dx.doi.org/10.29406/rj.v2i1.1340; Ridwan Arifin, Democracy on Indonesian Legal Reform: How Can People Participate on Laws and Regulations Establishment Process, JILS (Journal of Indonesian Legal Studies), 2(2), 2017, pp. 155-158. DOI: https://doi.org/10.15294/jils.v2i02.19439. Even for crimes conducted by children or juveniles have been negative steroypes, see Ria Juliana \& Ridwan Arifin, Anak dan Kejahatan (Faktor Penyebab dan Perlindungan Hukum), Jurnal Selat, Vol. 6 No. 2, 2019, pp. 225-234. DOI: https://doi.org/10.31629/selat.v6i2.1019

2 Law Number 4 of 1979 concerning Child Welfare and Law Number 23 of 2002 on Child Protection (State Gazette of The Republic of Indonesia of 2002 Number 109, Supplement to State Gazette of The Republic of Indonesia Number 4235).
} 
agencies that are closely related to the problem of delinquency in these children. ${ }^{3}$

Juvenile delinquency is an act committed by a child that is not in accordance with applicable regulations in the community, a child's mischief can be divided into ordinary delinquency and delinquency which is a criminal offense. Habits such as gathering together late into the night, scribbling on walls, speeding with vehicles on public roads are common delinquency, while juvenile delinquency which is a criminal offense is that his actions are threatened with the threat of criminal penalties, such as stealing, carrying out persecution, carrying weapons sharp, brawl, fighting with friends. ${ }^{4}$

The existence of children in our environment really needs attention, especially regarding their behavior. In the development towards adulthood, sometimes a child does something out of control and he/she does an act that is not good, so that it harms oneself and even others. The birth of Law Number 12 of 1995 concerning Corrections and Law Number 3 of 1997 concerning Juvenile Court which has been amended by Law Number 11 of 2012 concerning the Juvenile Justice System has provided a strong legal basis for discriminating treatment of children involved in a crime. Before the enactment of the Act, it was still very minimal legal regulations concerning the juvenile court. ${ }^{5}$

Facts that have shown about child delinquency problems, both spread through print and electronic media such as a junior high school student who committed theft at a stall near his school ${ }^{6}$, acts of rape committed by high

3 Ria Juliana \& Ridwan Arifin, Loc.cit; also see W.A. Bonger, Pengantar Tentang Kriminologi, Ghalia Indonesia, Jakarta, 1982, pp. 25-27.

4 Kartini Kartono, Pathologi Sosial Kenakalan Remaja, Rajawali Pers, Jakarta, 1992, pp. 37-39.

5 See Law Number 12 of 1995 concerning Corrections (State Gazette of The Republic of Indonesia of 1995 Number 77, Supplement To State Gazette of The Republic of Indonesia Number 3614); Law Number 3 of 1997 Concerning Juvenile Court (State Gazette of The Republic of Indonesia of 1997 Number 3, Supplement To State Gazette of The Republic of Indonesia Number 3668); Law Number 11 of 2012 Concerning The Juvenile Justice System (State Gazette of The Republic of Indonesia Year 2012 Number 153, Supplement To State Gazette of The Republic of Indonesia Number 5332).

6 Sandhi Nurhartanto, Mencuri 11 Kali, Seorang Pelajar SMP Diamankan, jatimnow, December 3, 2019, https://jatimnow.com/baca-21750-mencuri-11-kali-seorang-pelajarsmp-diamankan; Anonym, Curi HP, Siswi SMP ini Dihukum Minta Maaf Saat Upacara dan Fotonya Dipajang, detikNews, January 28, 2015, https://news.detik.com/berita-jawa-timur/d-2816565/curi-hp-siswi-smp-ini-dihukumminta-maaf-saat-upacara-dan-fotonya-dipajang 
school children against their female friends ${ }^{7}$, fights between children High school resulting in one student seriously injured in the city of Gorontalo, child abuse that started from illegal racing on the streets 8 , a child who could kill his father by stabbing twice, because it was suspected that his father had an affair 9 , and the seniors who mistreated younger classmates resulting in death, all of which are still elementary school children. ${ }^{10}$

The problem of children themselves, in Indonesia is a matter that really needs to be considered in the context of coaching young people. Regarding the punishment of children, this has been determined and formulated in Law Number 3 of 1997 concerning juvenile court and has been amended by Law Number 11 of 2012 concerning the Criminal Justice System for Children.

Based on 2008-2010 data, around 30 children were involved in delinquency. Among the delinquency cases of 17 children who committed offenses of abuse, the remainder was divided into cases of theft, molestation, embezzlement, etc. ${ }^{11}$ The phenomenon of criminal acts committed by children in various major cities in Indonesia has reached a chronic stage. In the city of Gorontalo, for example, the phenomenon of criminal acts committed by children has become a frequent thing in society and is very unsettling, many children commit acts of abuse, theft, molestation and various other things that cause children to come into contact with the law. The city of Gorontalo, where the community still upholds the customs, must deal with the behavior of children today where most of the children's behavior has crossed the line even children often commit criminal acts.

Although various efforts have been made by the local authorities to overcome this problem, the facts in the field show the increasing symptoms. From the background description of the problem above and to focus more on

7 Zulkifli, Kekerasan Seksual Anak di Gorontalo Kian Memprihatinkan, Ini Pesan KPAI untuk Orang Tua, Kronologi, December 19, 2018, https://kronologi.id/2018/12/19/kekerasan-seksual-anak-di-gorontalo-kian-

memprihatinkan-ini-pesan-kpai-untuk-orang-tua/

8 Ajis Halid, Diduga Dianiaya di Sekolah, Siswa SMA di Gorontalo Luka Lebam, detikNews, August 20, 2019, https://news.detik.com/berita/d-4673397/diduga-dianiayadi-sekolah-siswa-sma-di-gorontalo-luka-lebam; Christopel Paino, Siswa SMA dan SMK di Gorontalo Tawuran, Tempo, October 11, 2010, https://nasional.tempo.co/read/283941/siswa-sma-dan-smk-di-gorontalo-tawuran

9 Muhammad Gustirha Yunas, Diduga Selingkuh, Anak Tega Habisi Nyawa Ayahnya, Liputan 6, October 30, 2019, https://www.liputan6.com/news/read/4098659/didugaselingkuh-anak-tega-habisi-nyawa-ayahnya.

10 Fabian Januarius Kuwado, Polisi Telusuri Kasus Siswa SD Aniaya Adik Kelas Hingga Tewas, Kompas, May 4, 2014, https://tekno.kompas.com/read/2014/05/04/1900083/polisi.telusuri.kasus.siswa.sd.aniay a.adik.kelas.hingga.tewas.

11 Data from Gorontalo City Police Resort, 2010 
this writing, the formulation of the problem raised is as follows: (1). what are the factors that cause a crime committed by a child in the Gorontalo city area?, and (2) what are the efforts made to reduce or overcome the occurrence of criminal acts committed by children in the city of Gorontalo?

\section{B. Method}

The location of this research is in Gorontalo City, Gorontalo Province, with a focus of study in the Gorontalo City Police Office, Gorontalo District Court, Gorontalo State Prosecutor's Office, and Class II B Penitentiary in Gorontalo City. The main consideration for the authors choosing the city of Gorontalo as a research location is because the city of Gorontalo is the capital of the Gorontalo province and is one of the developing commercial cities whose people are still diverse, there are aspects of differences among the population, starting from cultural background, socioeconomic level and people's behavior. All of these are very prone to cause crimes committed by children.

The population in this research are including Children as perpetrators of crime (prisoners), all cases of violence committed by children, police officers, prosecutors, Judges and State Detention Center employees. The sample of the parties relating to criminal offenses committed by children, drawn samples using probability sampling and non probability sampling techniques. The samples for the police, prosecutors, judges, and officials of the State Class IIA Gorontalo detention center were carried out using probability sampling techniques. Gorontalo) 2 people, Judges (Gorontalo District Court) 2 people, Children of Criminal Actors (Gorontalo City Penitentiary) 30 people, As well as those who are competent in the Class II A State Detention House of Gorontalo who are considered to understand and know about things that are be the object of research.

The types of data used in this study are: Primary data, is data obtained through field research with related parties in connection with this research. Secondary data, is data obtained through literature studies, namely by examining the literature, articles, and legislation in force.

The data obtained are primary data and secondary data will be processed and analyzed based on the formulation of the problem that has been applied so that it is expected to obtain a clear picture of violence against children. Analysis of the data used is data analysis that seeks to provide a clear and concrete picture of the object that is discussed qualitatively and subsequently the data is presented descriptively that is explaining, describing, and describing in accordance with the problems that 
are closely related to research that uses frequency distribution test techniques with formula:

$$
\mathrm{P}=\frac{\mathrm{F}}{\mathrm{N} 100 \%} \begin{aligned}
& \begin{array}{l}
\text { Explanation: } \\
\mathrm{P}=\text { Percentage }
\end{array} \\
& \mathrm{F} \quad=\text { Frequency } \\
& \mathrm{N} \quad=\text { Number of Respondents } \\
& 100 \%=\text { Multiplier Number }
\end{aligned}
$$

The location of the study was conducted in the city of Gorontalo in the province of Gorontalo. Gorontalo City is one of the regions which is directly bordered by Gorontalo regency and Bonebolango Regency. Gorontalo City is divided into 6 subdistricts and consists of 49 villages / wards. The population according to Gorontalo City Statistics data for the period 20082012 detailed according to the total area population and population density as on Table 1

Table 1 Total population area and population density on 2008-2012

\begin{tabular}{cccc}
\hline Year & $\begin{array}{c}\text { Total population } \\
\text { (person) }\end{array}$ & Area $\left(\mathrm{km}^{2}\right)$ & $\begin{array}{c}\text { Population density } \\
\left(\text { person } / \mathrm{km}^{2}\right)\end{array}$ \\
\hline 2008 & 165.175 & $67,, 79$ & 2.594 \\
2009 & 181.102 & 67,79 & 2.795 \\
2010 & 184.185 & 67,79 & 2.842 \\
2011 & 186.193 & 67,79 & 2.924 \\
2012 & 190.176 & 67,79 & 3.014 \\
\hline
\end{tabular}

Source: Gorontalo City Central Statistics Agency

Table 1 showed that until 2012 the population in Gorontalo City increased, but the area of Gorontalo City never increased, making it very easy for social insecurity to occur in the community. Most of Gorontalo residents work as civil servants, both civil servants and private employees, because there are still many job vacancies in Gorontalo, but there are also many Gorontalo residents who work as farmers, fishermen, and bearers of bentor or as entrepreneurs, in general all types the work in the city of Gorontalo is evenly distributed to each resident.

\section{Result and Discussion \\ 1. Criminal Acts Conducted by Children in Gorontalo City on 2008-2012}




\section{a. Gorontalo City Police Data}

To find out the level of development of criminal offenses committed by children in the city of Gorontalo in 2008 to 2012, the study was conducted at the Gorontalo City police station, for more details presented in the form of as on Table 2.

Table 2 forms of criminal acts committed by children in the city of Gorontalo from 2008-2012

\begin{tabular}{|c|l|c|c|c|c|c|}
\hline No & $\begin{array}{c}\text { Types of criminal acts } \\
\text { committed by children }\end{array}$ & 2008 & 2009 & 2010 & 2011 & 2012 \\
\hline 1 & Persecution and violence & 2 & 1 & 3 & 3 & 4 \\
\hline 2 & Theft & 1 & - & 2 & 2 & 3 \\
\hline 3 & Murder & - & - & - & - & - \\
\hline 4 & Sexual abuse & 2 & 1 & 2 & 3 & 3 \\
\hline 5 & Rape & - & - & - & - & - \\
\hline
\end{tabular}

Source: Gorontalo City Police of 2008-2012

Based on the results of an interview with AKP Nenank Sulistianita who must as the protection of women and children, he said that the association of children today is very worrying, many children are wrong to get along so that children can take actions that cause the child to come into contact with the law, child association becomes very uncontrolled, especially the role of parents in the child's association is very minimal, parents do not know their children associate with who and what is done by the child when hanging out in their environment, children also do not understand the consequences of the actions they do.

Not all cases that exist in Gorontalo city police are delegated to the prosecutor's office for further processing, because the police can now take actions where children who commit a crime are returned to their parents, or reconciled with victims, commonly referred to as police diversity. However, for acts of diversion the police are only in the form of minor criminal offenses such as minor maltreatment, theft carried out within the scope of the family.

\section{b. Gorontalo District Prosecutors' Data}

The data obtained from the Gorontalo District Prosecutors' Office are slightly different from the data obtained at the Gorontalo City Police Precinct because criminal cases committed by children handed over to the Prosecutor's Office are not only cases contained in the Gorontalo City Police Precinct, but there are also a number of cases that are bestowed on prosecutors through the precincts in the city of Gorontalo, as on Table 3. 
Table 3 Crimes committed by children in the city of Gorontalo from 2008-

2012

\begin{tabular}{|c|l|c|c|c|c|c|}
\hline No & $\begin{array}{c}\text { Types of criminal acts } \\
\text { committed by children }\end{array}$ & 2008 & 2009 & 2010 & 2011 & 2012 \\
\hline 1 & Persecution and violence & 2 & 9 & 5 & 8 & 8 \\
\hline 2 & Theft & 2 & 10 & 4 & 5 & 4 \\
\hline 3 & Murder & - & - & - & - & - \\
\hline 4 & Sexual abuse & - & 5 & - & 1 & 3 \\
\hline 5 & Rape & - & - & - & - & - \\
\hline
\end{tabular}

Source: Gorontalo District Prosecutor's Office

Based on data obtained from the Gorontalo District Attorney's Office there are many cases of criminal acts committed by children, especially in the abuse and theft. According to Buchari Taslim Tuasikal, SH Head of General Crime Office of the Gorontalo District Prosecutor's Office, that for many cases of child abuse that have been delegated to the prosecutor's office, many children commit acts of abuse because children do not know the consequences that will be received. When carrying out these actions, the factors of association and upbringing from the family which makes it easy for children to commit acts of abuse, usually the children do the abuse to their peers or peers, but there are also children who commit acts of mistreatment to older people but are carried out jointly with her friend.

\section{c. Data of Gorontalo Class II Correctional Institution}

To obtain primary data about the causes of the crime committed by children in the city of Gorontalo, the data is directly obtained from the perpetrators in the Correctional Institution Class IIA of Gorontalo, while the number of perpetrators of criminal acts committed by children as shown on Table 4.

Table 4 Crimes committed by children in the city of Gorontalo in 2008-2012

\begin{tabular}{|c|l|c|c|c|}
\hline No & Types of criminal offenses & Amount & Age & Sex \\
\hline 1 & Persecution and violence & 12 & $14-17$ & Men \\
\hline 2 & Theft & 14 & $12-17$ & Men \\
\hline 3 & Murder & - & - & - \\
\hline 4 & Sexual abuse & 4 & $13-17$ & Men \\
\hline 5 & Rape & - & - & - \\
\hline
\end{tabular}

Source: Class IIA Correctional Institution of Gorontalo

Table 4 emphasizes that the crime committed by children of age interval is between 13 years to 17 years. A person's age is very influential in the maturity of thinking, especially the maturity in distinguishing deeds that are proper and inappropriate. They have realized and felt the meaning and 
responsibility for fulfilling the needs of life itself. Age in certain respects still allows one to become deeper into the dynamics of the psyche.

Humans when viewed as objects in a wave of crime, it is related to the level of age, first he commits crimes against property, then commits violent offenses such as persecution and murder, after that he tends to commit crimes of forgery, as well as crime decency is often done by people who reach adulthood. As a problem that has an influence on a person's attitude, the age factor is considered to be very important in influencing someone to take an action, especially an act against the law.

\section{Factors Causing the Occurrence of Crimes committed by Children in Gorontalo City}

Based on the results of research obtained in the field by using several approaches including Questionnaires, Interviews, and Documentation, there are several factors that influence children to commit criminal acts, while those factors as follows.

\section{a. Family Social Environments Factors}

The family environment is one of the special groups that first affect a child's life. The family is the beginning of life from the life of a newborn child. In the family, a child learns to play a role as a social creature that has certain norms and skills in association in the midst of society. The experiences gained in the family really determine the ways of behaving of a child with an environment outside the family, namely the community environment.

Factors that also influence the occurrence of crimes committed by children are social factors. A bad environment, where there is a lot of unemployment, many places where liquor is a potential for the birth of delinquency and leads to criminal offenses of children and adults in general.

\section{b. Socio-Economic Conditions Factors}

Economic influence is often carried out research by criminology disciplines to study the relationship between socio-economic conditions and crime rates, arguing that indeed as long as the socio-economic condition is an aspect of social behaviour and it certainly cannot be excluded against the emergence of various kinds of crime. ${ }^{12}$

12 Topo Santoso \& Eva Achjani Zulva, Kriminologi, Raja Grafindo Persada, Jakarta, 2002, pp. 78-79; Romli Atmasasmita, Teori dan Kapita Selekta Kriminologi, Eresco, Jakarta, 1992, p. 37; J.E. Sahetapy, Pisau Analisa Kriminologi, Armico, Bandung, 1983, p. 45; B. Simanjuntak, Pengantar Kriminologi, Tarsito Bandung, 1981, p. 59. 
Socioeconomic conditions have a close relationship with employment status. With someone's erratic work, it's rather difficult to pay for their daily needs, if if someone is married/has a family and already has children, then the possibility of pressure will always be there. ${ }^{13}$

Thus, the socio-economic condition of the offender's parents has proved to have an important role in supporting a child to be neglected, naughty and evil. Therefore basically poverty will cause great danger to the human soul. In connection with this to see the low socioeconomic status of the perpetrators of crime is the work of the perpetrators' parents. It turns out that many of them have parents who work as motorbike pedicab drivers (becak motor, or bentor), unskilled laborers and some even have erratic jobs.

Thus it can be qualified that the low income of their parents can lead to criminal acts. This is possible because the condition of parents who are busy making a living so that there is no attention to children. In addition, parents are also not able to meet all the needs that children want, so children tend to no longer listen to the advice of their parents. These children then become wild and can no longer be controlled. Weakening of the control function causes social ties with parents and the community to be broken.

\section{c. Factors of Low Education Level}

Formal education is the second educational tool or facility after the family environment for a child. Where major cities in Indonesia today, especially in the city of Gorontalo, adolescence is still a period of school, especially in the early days, where the period is generally children are still in junior high school or the equivalent. However, this fact cannot be denied that a child who has dropped out of school is not the least caused by various factors that can hinder the educational process of the child concerned.

The lack of school facilities and infrastructure is one of the factors causing children to drop out of school, in addition to other factors such as the ability of children's parents to be unable to pay for their children to a higher level of education. High and low formal education of a child or society in general, is very decisive in every attitude and behavior in daily life in the community.

Therefore it seems to play an important role in human life, when compared with other institutions. Thus, a low education can also be said to be narrow-minded so that it is easily influenced by bad behavior through actions that can harm others. One thing that needs to be pointed out here,

13 Kartini Kartono, Pathologi Sosial Kenakalan Remaja, Rajawali Pers, Jakarta, 1992, pp. 66-69 
that the low level of education is not absolutely a major cause of crime, especially those committed by children in the city of Gorontalo. But this cannot be denied, because many cases of crimes committed by children of educational level are very low.

\section{d. Alcohol as a Psychological Factor}

One psychological factor for children is alcoholism. Most of them think that consuming alcoholic drinks can increase energy, increase selfconfidence, or as a remedy for feelings of disappointment, mental stress, anxiety and tension due to the problems being faced. Children often also assume that after consuming alcoholic drinks there is a feeling of loss of fear, feeling himself the most great so that children are free to do something without having to think about others. Most of them consume alcohol because of a complex background, fad or want to adjust to the group of friends.

So children who often consume liquor will be easier to commit a crime compared to those who have never consumed liquor, this is due to liquor can make a child's psychological damage so that all actions and behavior can not be controlled which results in children dealing with the law.

\section{e. Religious Factors}

Religious factors are very important in controlling one's personality, especially children. Children who are devout worship will avoid deviant behavior let alone commit a crime. Children must be taught early on matters of religion so that children know what he must do and can control all actions that he will do.

\section{The Effort for Juvenile Crimes Prevention in Gorontalo}

Efforts to deal with criminal acts committed by children are basically carried out by:

\section{a. Preventive Efforts}

Preventive efforts undertaken or taken in the context of improving, controlling and monitoring the behavior of children and their environment include, among others:

\section{1) Guidance and Counseling}

Efforts to tackle crimes committed by children in the form of counseling is an effort to prevent crime in an effort to prevent the occurrence of crime for the first time, meaning that this effort is a basic effort given to potential perpetrators of crime in order to gain an understanding of the impact and consequences that will be obtained if 
committing a crime. Efforts in the form of counseling can be done alone by the police who work directly with related parties in the crime prevention effort.

2) Involving Communities in Positive Organizations

The formation of well-coordinated associations or clubs such as the formation of youth clubs, the formation of youth mosques, sports clubs and so on will channel the talents and aspirations of the younger generation. The talent that is channeled is more beneficial when it can be used as a source of income and at the same time opening new jobs, thereby reducing unemployment in the city of Gorontalo.

3) Role of the Family

The family provides an important role in the development of children even as a foundation for the personality of a child. Therefore parents who are responsible for looking after their children should be able to give full love so that the child feels as if he has never lost his father and mother. Besides that, the physical needs of the child must also be met as appropriate so that the child is protected from unlawful acts. In dealing with child crime and delinquency, parents should be able to provide the following actions:

a) The importance of a close relationship between parent and child;

b) Instill good mental character in children;

c) Provide supervision and protection of children;

d) Instill discipline in children, and teach religious values to children from an early age.

Efforts to overcome crimes committed by children in the city of Gorontalo in a preventive manner, the municipal police of Gorontalo take actions such as raiding places and goods that can be used as places and tools for committing crimes by children, organizing control of children's ganks which disrupt public order, control of illegal races, control of sharp objects carried by children, and tighten supervision of crime-prone areas.

\section{b. Repressive Efforts}

This repressive effort is an attempt made to deal with criminal offenses committed by children that have already occurred. In principle, every action when dealing with forms of delinquency and crime in children in any process must be educating and helping children to be aware of their actions, and return to the family and community well. ${ }^{14}$ This also includes assisting

14 Andi Zainal Abidin Farid, Bunga Rampai Hukum Pidana, Pradnya Paramita, Jakarta, 1983, p. 57; see also Andi Zainal Abidin Farid, Hukum Pidana I, Sinar Grafika, Jakarta, 1995, pp. 77-79; A.S. Alam, Pengantar Kriminologi, Pustaka Refleksi, 
officers to find ways or ways of appropriate solutions to problems of crime committed by children. As for the repressive efforts carried out as follows:

1) Investigation

In carrying out this action, Gorontalo City Police first considered and considered what was considered necessary, including:

a) In conducting an interrogation conducted in a family atmosphere in a calm atmosphere, so that the child feels safe and is not afraid

b) In the examination of children suspected of committing criminal offenses, parents/guardians must be accompanied if this is deemed necessary.

c) The examiner is authorized to present an expert and listen to the expert's information, regarding the actions committed by the child who committed the crime, which can later be used as a consideration in the examination.

\section{2) Detention}

The principle of detention carried out by Gorontalo municipal police of children who commit crimes is required to be the same as the principles of adult detention, but there are exceptions in certain matters that are deemed necessary in order to maintain the stability and security of a child who commits a crime, including:

a) Detention of the child is interpreted as an effort to protect the child

b) During detention, the child is allowed to keep in contact with parents or guardians and their families, besides that the child still gets his right to study.

c) While in detention, the child is given services such as health services, food and neat clothes.

d) The children are detained only as necessary, and most of them are returned to their parents or guardians, in the sense that they are detained outside (at home only), but remain under surveillance.

3) Prosecution

In prosecuting cases of children who commit a crime is to pay attention to the age of the child, because it relates to a shorter child detention time, the file handed over by the police has been equipped with a social research report on a child suspect by Penitentiary (Balai Pemasyarakatan, or BAPAS) and also investigated whether the offense committed by the child done with an adult, the case file must be separated (splitzing). After that, it can be determined whether the case file meets the requirements or not to proceed to the court stage.

Makassar, 2010, pp. 21-23; Moeljatno, Asas-Asas Hukum Pidana, Bina Aksara, Jakarta, 1987, pp. 30-32. 
4) Trial Examination

The principles that must be considered by every judge in passing the verdict on children who commit a crime include:

a) The trial is held separately from the trial and the court procedures involving parents

b) Child trials are conducted in private, which aims to protect children, because if the trial is witnessed by the community there will be an assumption that the child is a bad person and guilty even though in this case they are not necessarily guilty because they are still in the process of examination, and this certainly alone is bad for the child's mental development.

c) The trial was attended by the parents or guardians concerned, with no permission of the press to attend the hearing

d) Judges appointed to preside over hearings are judges appointed specifically for this matter and represent their knowledge and special attention to children's problems

e) Judges are obliged to work on Diversity no later than 7 days after being determined by the head of the district court as a judge

f) The child has the right to be accompanied by a parent/guardian or guardian, legal counsel or other legal aid provider, and social counselor to assist the child.

g) The judge's decision must consider the social research report and the social counselor and is based on case studies, case reports and the views of expert witnesses

h) Judges' decisions are not burdensome, but help and protect so that the child can regret and be aware of the deeds and will not repeat the crimes that have been committed

i) The decision taken by the judge is the final decision which determines the fate of the child, so in making a decision, the judge must be careful to pay attention to many factors that affect the child, so the provision of imprisonment is the final decision to be taken.

\section{c. Rehabilitation Efforts}

Basically, bad children must be improved their attitude, behavior and mental condition, therefore the purpose of this rehabilitation is to prioritize the future interests of children who have committed a crime. 
In principle, special coaching is done wherever possible at the parents' home or wallinya, and if it turns out according to the judge's consideration that the child cannot be returned to the parent or guardian, the State is responsible for fostering the child through a job training or coaching institute held both by the government and the private sector. Actions that can be taken on bad children are:

1) Returning to parents / guardians;

2) Submission to someone;

3) Treatment in a mental hospital;

4) Treatment at LPKS (Institute for Social Welfare);

5) Obligation to attend formal education and / or training provided by the government or private bodies;

6) Revocation of driving license;

7) Repairs due to criminal acts.

\section{Conclusion}

This research concludes that criminal offenses committed by children in Gorontalo city are influenced by several factors including: family and social environment factors, economic conditions, factors of the low level of education of perpetrators of crime, factors that often consume liquor and factors that lack knowledge The religion of the child who committed the crime. How to cope with criminal acts committed by children in the city of Gorontalo in broad outlines carried out three efforts, namely: (1) preventive efforts (prevention), (2) repressive efforts (repression), and efforts to repair and guidance (rehabilitation/curative).

\section{E. Acknowledgments}

These remarks were conveyed to the University of Janabadra, Tegalrejo Sub-District Head, village head, community leaders, Karang Taruna Tegalrejo Chairperson and all the organizers of the legal hazard education activities.

\section{F. Declaration of Conflicting Interests}

The authors state that there is no potential conflict of interest in the research, authorship, and / or publication / publication of this article. 


\section{G. Funding}

None

\section{H. References}

Alam, A.S. (2010). Pengantar Kriminologi. Makassar: Pustaka Refleksi. Anonym. (2015). Curi HP, Siswi SMP ini Dihukum Minta Maaf Saat Upacara dan Fotonya Dipajang, detikNews, January 28, https://news.detik.com/berita-jawa-timur/d-2816565/curi-hp-siswismp-ini-dihukum-minta-maaf-saat-upacara-dan-fotonya-dipajang

Arifin, R. (2017). Democracy on Indonesian Legal Reform: How Can People Participate on Laws and Regulations Establishment Process, JILS (Journal of Indonesian Legal Studies), 2(2), 155-158. DOI: https://doi.org/10.15294/jils.v2i02.19439.

Atmasasmita, R. (1992). Teori dan Kapita Selekta Kriminologi. Jakarta: Eresco.

Bonger, W.A. (1982). Pengantar Tentang Kriminologi. Jakarta: Ghalia Indonesia.

Data from Gorontalo City Police Resort, 2010

Farid, A.Z.A. (1983). Bunga Rampai Hukum Pidana. Jakarta: Pradnya Paramita.

Farid, A.Z.A. (1995). Hukum Pidana I. Jakarta: Sinar Grafika.

Halid, A. (2019). Diduga Dianiaya di Sekolah, Siswa SMA di Gorontalo Luka Lebam, detikNews, August 20, https://news.detik.com/berita/d4673397/diduga-dianiaya-di-sekolah-siswa-sma-di-gorontalo-lukalebam

Juliana R., \& Arifin, R. (2019). Anak dan Kejahatan (Faktor Penyebab dan Perlindungan Hukum), Jurnal Selat, 6(2), 225-234. DOI: https://doi.org/10.31629/selat.v6i2.1019

Kartono, K. (1992). Pathologi Sosial Kenakalan Remaja. Jakarta: Rajawali Pers.

Kuwado, F.J. (2014). Polisi Telusuri Kasus Siswa SD Aniaya Adik Kelas Hingga Tewas, Kompas, May 4, https://tekno.kompas.com/read/2014/05/04/1900083/polisi.telusuri.kas us.siswa.sd.aniaya.adik.kelas.hingga.tewas.

Law Number 4 of 1979 concerning Child Welfare and Law Number 23 of 2002 on Child Protection (State Gazette of The Republic of Indonesia of 2002 Number 109, Supplement to State Gazette of The Republic of Indonesia Number 4235).

Law Number 12 of 1995 concerning Corrections (State Gazette of The Republic of Indonesia of 1995 Number 77, Supplement To State Gazette of The Republic of Indonesia Number 3614) 
Law Number 3 of 1997 Concerning Juvenile Court (State Gazette of The Republic of Indonesia of 1997 Number 3, Supplement To State Gazette of The Republic of Indonesia Number 3668)

Law Number 11 of 2012 Concerning The Juvenile Justice System (State Gazette of The Republic of Indonesia Year 2012 Number 153, Supplement To State Gazette of The Republic of Indonesia Number 5332).

Moeljatno, M. (1987). Asas-Asas Hukum Pidana. Jakarta: Bina Aksara.

Nurhartanto, S. (2009). Mencuri 11 Kali, Seorang Pelajar SMP Diamankan, jatimnow, December 3, https://jatimnow.com/baca-21750-mencuri-11kali-seorang-pelajar-smp-diamankan

Paino, C. (2010). Siswa SMA dan SMK di Gorontalo Tawuran, Tempo, October 11, https://nasional.tempo.co/read/283941/siswa-sma-dansmk-di-gorontalo-tawuran

Putri, A.R.H. \& Arifin, R. (2019). Perlindungan Hukum Bagi Korban Tindak Pidana Perdagangan Orang Di Indonesia (Legal Protection for Victims of Human Trafficking Crimes in Indonesia), Res Judicata, 2(1), 170-185. DOI: http://dx.doi.org/10.29406/rj.v2i1.1340

Sahetapy, J.E. (1983). Pisau Analisa Kriminologi. Bandung: Armico.

Santoso, T. \& Zulva, E.A. (2002). Kriminologi. Jakarta: Raja Grafindo Persada.

Simanjuntak, B. (1981). Pengantar Kriminologi. Bandung: Tarsito.

Yunas, M.G. (2019). Diduga Selingkuh, Anak Tega Habisi Nyawa Ayahnya, Liputan 6, October 30, https://www.liputan6.com/news/read/4098659/diduga-selingkuhanak-tega-habisi-nyawa-ayahnya.

Zulkifli, Z. (2018). Kekerasan Seksual Anak di Gorontalo Kian Memprihatinkan, Ini Pesan KPAI untuk Orang Tua, Kronologi, December 19, https://kronologi.id/2018/12/19/kekerasan-seksualanak-di-gorontalo-kian-memprihatinkan-ini-pesan-kpai-untuk-orangtual 


\title{
QUOTE
}

\section{Strength does not come from physical capacity. It comes from an indomitable will.}

\author{
Mahatma Gandhi
}

Copyrights (C) 2020 by Auhtor(s). This work is licensed under a Creative Commons Attribution-NonCommercial-ShareAlike 4.0 International License. All writings published in this journal are personal views of the authors and do not represent the views of this journal and the author's affiliated institutions. 